\title{
MRS Committees Announce 1987 Priorities
}

\author{
Education, Finance, Nominating, Public Relations, and \\ Publications Committees Expand Goals
}

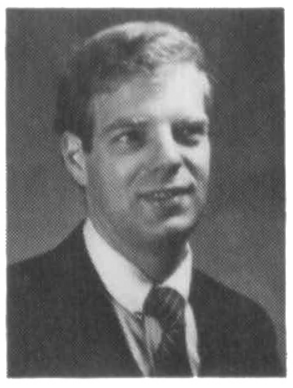

A.D. Romig, Jr.

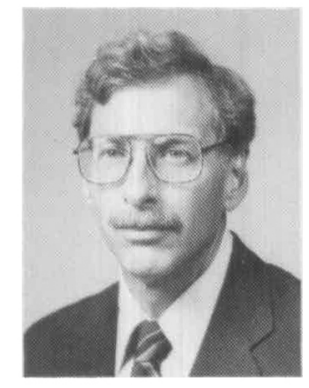

G.G. Tibbetts

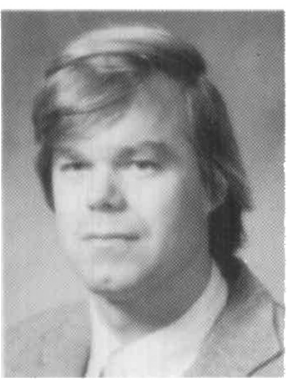

C.W. Draper

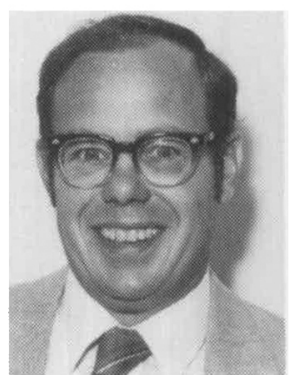

G.E. Pike

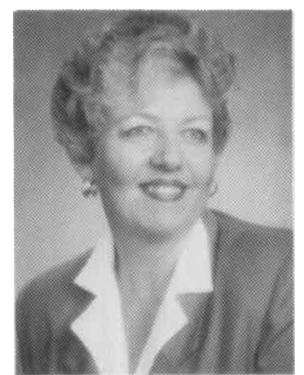

C.M. Jantzen

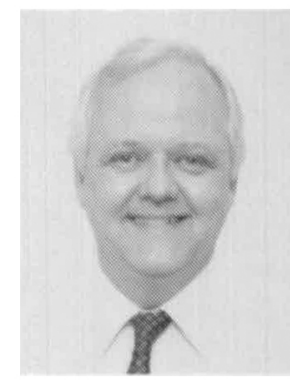

D.R. Campbell
In the previous issue of the MRS BULLETIN (p. 69), the chairs of the Awards, Corporate Participation, External Affairs, Long Range Planning, Membership, and Program committees defined their goals and activities for 1987. In this issue, the chairs for the remaining committees - Education-Short Courses, Education-Universities, Finance, Nominating, Public Relations and Publicity, and Publications - announce their priorities for 1987.

The work of the committees sustains the myriad of professional services offered to MRS members. As the Society continues to experience a high level of growth, the committees play an important role in instituting new dimensions for existing projects and in recommending changes in policies and procedures to the MRS Council. MRS members are encouraged to contact the committee chairs to offer advice, suggestions, or assistance.

\section{Education Committee - Short Courses}

Cochair: Alton D. Romig, Jr., Sandia

National Laboratories, Albuquerque, NM; telephone (505) 844-8358

The Education Committee subcommittee responsible for the MRS Short Course Program is striving (1) to serve the MRS membership; (2) to serve the scientific and technical community in general; (3) to complement the technical program at MRS meetings; and (4) to assist the academic community by offering scholarships to students to attend MRS short courses.

To meet these goals the Education Committee is developing the short course program based upon materials science themes as well as developing specialized courses on subjects which often relate to the technical program of MRS meetings. The short course program strives to be broad, dynamic, and responsive in terms of the topics offered as well as in the technical depth of the courses. Some courses are of an advanced nature intended for people active in the field, while others are intended for newcomers to the field and may be given at a technological rather than a scientific level. For the past several years, the short course program has evolved to meet these needs by developing high quality courses which have a range of scientific, engineering, and technological orientations. Continuing change in the short course program will continue to fulfill these needs.

The Education Committee also believes that the best program is one which focuses primarily on several technical themes, rather than being merely a collection of courses. As a result, a course is presented not only because it is deemed a good one, but because it contributes to a specific technical area. The technical themes and specialized topics which have been pursued and which are continuing to receive attention are described in detail in the Short Course News section of this issue of the BULLETIN.

In addition to a short course program of high quality at the MRS Fall and Spring Meetings, an active On-Site short course program is being developed. Existing short courses in the MRS portfolio are presented at the site of a requesting organization. In addition, the On-Site program responds to specific requests for new courses in technical areas not currently being addressed by the short course programs of other societies, professional educational organizations, or universities. This latter aspect of the On-Site program is considered particularly important.

In 1986 the first "hands-on" course was presented in conjunction with a university laboratory facility as a Stand-Alone program (a course not offered in conjunction with an MRS meeting). Future opportunities to continue this approach will be explored.

Last, but certainly not least, an important goal of the short course program is to assist qualified advanced students to benefit from the program. A limited number of scholarships are offered in all courses. Concerted efforts are being made to ensure that the existence of these scholarships is more widely known by the MRS Student Chapters and the academic community in general.

\section{Education Committee - Universities \\ Cochair: Gary G. Tibbetts, General Motors Research Laboratories, Warren, MI; telephone (313) 986-0655}

The primary task of this portion of the Education Committee is to nurture the ten newly formed MRS Student Chapters on university campuses and to promote the formation of chapters at other universities. At this stage of rapid growth of materials science, we would like to ensure that as many students as possible are exposed to the creative nature of interdisciplinary research on materials.

MRS has provided significant benefits for students. These benefits, open to all students pursuing degrees in materials science disciplines, include reduced fees for MRS membership and registration at MRS meetings, and reduced tuition scholarships for MRS short courses. Additional benefits for MRS Student Chapter members include sizeable travel grants to attend MRS meetings, and a list of "Distinguished Speakers" available for MRS Student Chapter programs. The requirements for formation of a Student Chapter are not complicated: a petition for recognition requires only the signatures of three students and two full MRS members. Readers who wish more complete information are encouraged to call Gary Tibbetts at the above phone number.

We hope to improve communications with the Student Chapters by assigning each committee member primary responsibility for one existing Student Chapter and one group in the process of forming a chapter. We hope to see significant growth in both the quality and quantity of MRS representation on university campuses this year.

Continued 


\section{Finance Committee}

Chair: Clif W. Draper, ATET Engineering

Research Center, Princeton, NJ; telephone (609) 639-2350

The MRS Finance Committee is a small working group with several specific and fundamentally important tasks. The most preeminent of these is drafting the Society budget each year. The committee collects income and expense estimates from every aspect of the Society's "business," and drafts a next-year look for the elected Officers and Councillors to approve at the Spring Meeting.

The preparation of a two-million-dollarplus budget for an organization, which is still very much volunteer and "seat of the pants," is both frustrating and rewarding. Following the budget cycle, and to some extent continuing year round, it is the Finance Committee's responsibility to aid the Treasurer in tracking our actual income and expense versus that budget. We raise red flags when appropriate, and more importantly we cycle that learning curve information into the next year's budget process.

In the revenue area, the committee has both short-term and long-term goals. In the current year we will be looking to help raise revenue through avenues our Society has not yet explored. We will be looking carefully at the use of the sizeable marketing list we have developed over the last several years. The use of our marketing list will not generate large quantities of money, but can result in enough income to potentially support some special young scientist or student awards.

In the years to come the Society will face some decisions that will have a serious financial impact-decisions about a permanent headquarters building in Pittsburgh, about the "equilibrium" meeting size, and about the "final" size of our staff when the Society membership begins to level off. Good financial planning will be essential if we are to address these issues and not burden ourselves with climbing registration fees and book prices.

\section{Nominating Committee}

Chair: Gordon E. Pike, Sandia National

Laboratories, Albuquerque, NM; telephone (505) 844-7562

It is the responsibility of the Nominating Committee to identify outstanding individuals to serve the Society as either Officers or Councillors. This committee then creates a slate of these nominations, by position, and submits the slate to Council for approval in July. A ballot is then prepared for the MRS membership, and the vote is taken during August. This year the Society will elect five Councillors for terms of three years each, and a First and a Second Vice President for terms of one year (although the First Vice President is also President Elect).
It is important for a broadly based society such as MRS to nominate a slate of people who are not only respected and capable, but also represent the diverse interests of the membership. Indeed, the MRS Bylaws charge the committee to be "sensitive to an appropriate balance... in terms of affiliation, technical background, gender, and regional location." To help ensure this sensitivity Chairman Gordon Pike has reviewed the composition of the Nominating Committee, and has enlarged it by adding prominent members in areas previously without adequate voice. The committee members are listed below, and you are encouraged to approach any of them with suggestions for nominations.

1987 Nominating Committee: G.E. Pike, Chair, Sandia National Laboratories; B.R. Appleton, Oak Ridge National Laboratory; J.E.E. Baglin, IBM T.J. Watson Research Center; D.K. Biegelsen, Xerox Palo Alto Research Center; W.L. Brown, AT\&T Bell Laboratories; R.H. Doremus, Rensselaer Polytechnic Institute; C.W. Draper, AT\&T Engineering Research Center; R. C. Ewing, University of New Mexico; E.N. Kaufmann, Lawrence Livermore National Laboratory; B.H. Kear, Rutgers University; D.E. Passoja, Consultant; D.M. Roy, Pennsylvania State University; R.L. Schwoebel, Sandia National Laboratories; K.C. Taylor, General Motors Research Laboratories; and C.W. White, Oak Ridge National Laboratory.

\section{Public Relations and Publicity \\ Chair: C.M. Jantzen, E.I. du Pont \\ deNemours \& Co., Savannah River Laboratory, Aiken, SC; telephone (803) 725-2374}

The Public Relations and Publicity Committee was established in 1984 in response to the growing interdisciplinary role of the Society as the major forum for materials research. The focus of the committee between 1984 and 1987 was to publicize MRS activities to members through the BULLETIN, publicize MRS activities to nonmembers through articles and calender entries in appropriate journals, and arrange for press coverage at Society meetings. The committee currently works with MRS headquarters to continue and enhance this role.

Over the next three years the committee will focus on developing the role of MRS as the vital link between fundamental research and the technological advances which benefit society. The committee will enhance the technical community's awareness of MRS as well as increase the general public's perception of MRS and the technology it represents. This year the committee will also solicit from the MRS membership material for feature articles in technical journals, popular journals, the science sections of major newspapers, and television news networks.
The current Public Relations and Publicity committee was formed in January 1987 with representatives on the East Coast, West Coast, and Europe as well as at MRS headquarters. The committee representatives will serve for three years so that continuity can be achieved and long-range contacts in the technical community and with the press can be preserved. This year the committee hopes to develop increased coordination with E-MRS, with the Education Committee, Corporate Participation Committee, and with the Short Course organizers.

Change and opportunity are the keys to progress. MRS has progressed as a result of both, and the Public Relations and Publicity Committee hopes to pursue all possible opportunities to help MRS and its members progress. We ask for any and all suggestions from the MRS membership.

\section{Publications Committee}

Chair: D.R. Campbell, IBM East Fishkill

Facilities, Hopewell Junction, NY; telephone (914) 894-3075

The MRS Publications Committee continues to foster the growth of three large projects in 1987: Journal of Materials Research, book publications, and the MRS BULLETIN. The various functions of these three areas are overseen by their respective chairs: Jeff Gambino, IBM, chair of the subcommittee on journals; Peter Pronko, Universal Energy Systems, chair of the subcommittee on books; and Elton Kaufmann, chair of the BULLETIN editorial board.

A primary mission of the subcommittee on journals is to seek out important manuscripts for Journal of Materials Research at both the Spring and Fall MRS meetings. Symposia chairs and reviewers of manuscripts submitted for publication in the various symposia held at the Spring Meeting will be asked to nominate papers of exceptional quality for consideration for publication in JMR. In general, manuscripts originally prepared for publication in an MRS proceedings volume are not appropriate in that form for IMR; however, complete and finalized accounts of research efforts which often stem from MRS symposia presentations are sought for inclusion in this new interdisciplinary journal. The subcommittee on journals will also focus on increasing $J M R$ subscriptions in technical libraries, particularly those in Europe and Asia. The Publications Committee wishes to ensure that $J M R$ is available to scientists worldwide.

The subcommittee on books will focus on two activities: (1) ensuring the ongoing rapid publication of high-quality MRS proceedings volumes from the symposia papers submitted at the Spring and Fall meetings, and (2) investigating the possible expansion of book publishing opera-

Continued 
tions to encompass proceedings from other important scientific meetings, technical monographs, and educational materials. The first volume of a new, non-MRS, proceedings series was published in 1986 and several additions to this new series are anticipated for 1987. Candidate manuscripts for initiating a new technical monograph series are sought for consideration in this series. This series is logically expected to undergo dramatically rapid growth based on the estimated capacity of the MRS membership for sustained scientific achievement in their chosen fields and the inevitable expression of that achievement through superb technical monographs.

The MRS BULLETIN, having undergone explosive growth over the past few years, will continue its expansion in many directions. The BULLETIN has changed emphasis from that of its inception, as a vehicle primarily for Society news, to a vigorous, technically oriented publication that covers all the significant developments and trends in materials research. The subcommittee will concentrate its efforts on soliciting technical review articles on forefront materials research areas, expanding national and international news coverage of research programs, and offering MRS members and other materials research professionals the opportunity to voice opinions and ideas.

The MRS publications program continues to expand into new endeavors in order to provide the MRS membership with informational services of the highest caliber. This is an ongoing emphasis within the Publications Committee and all MRS members are encouraged to contribute their ideas and services in any of these areas.

\section{MATERIALS RESEARCH SOCIETY 1987 Committee Chairs}

Committees

*Awards

*Corporate Participation

Education-Short Courses

Education-University Issues

*External Affairs

Finance

*Long Range Planning

*Membership

Nominating

*Program

Public Relations

\& Publicity

Publications
Chaired or Cochaired by

G.E. Pike, (505) 844-7562

L.M. Quick, (201) 321-5590

A.D. Romig, Cochair, (505) 844-8358

G. Tibbets, Cochair, (313) 986-0655

E.N. Kaufmann, (415) 423-2640

C.W. Draper (609) 639-2350

G.E. Pike, (505) 844-7562

J.M. Phillips, (201) 582-4428

G.E. Pike, (505) 844-7562

R.K. Quinn, (505) 667-6250

J.B. Roberto, Vice Chair, (615) 576-0227 